\title{
THE APPLICATION OF CZEKANOWSKI DIAGRAM TO ASSESS THE FINANCIAL SITUATION OF NON-FINANCIAL ENTERPRISES IN POLAND IN THE YEARS 2010-2020
}

\author{
Monika MIŚKIEWICZ-NAWROCKA \\ University of Economics in Katowice; monika.miskiewicz@ue.katowice.pl, ORCID: 0000-0002-2766-1322
}

Purpose: The changing financial situation of enterprises under the influence of various political, economic, social, etc. decisions is the cause of interest of many researchers. The aim of the research is to assess the financial situation of non-financial enterprises in Polish voivodships, taking into account the division into the private sector and the public sector in 2010-2020, and an attempt to classify the analyzed voivodeships into separate classes.

Design/methodology/approach: Czekanowski's method was used to achieve the goal, which allows for the comparison of the examined objects in terms of the analyzed phenomenon. The visualization of this method is an ordered Czekanowski diagram, on the basis of which it is possible to group objects and observe whether their geographic location influences the results of grouping.

Findings: The conducted analysis made it possible to group voivodeships in terms of the financial situation of enterprises, both for the public and private sectors. In the analyzed period, among the voivodships of Poland, several groups of similar voivodships can be distinguished in terms of the financial situation of enterprises. A voivodship was also selected, which differs from the rest of the voivodships - it is characterized by a lack of similarity in terms of the considered features, both in the whole analyzed period. It was also shown that the lockdown resulting from the SARS-CoV-2 pandemic had a significant impact on the financial results of Polish enterprises in the first half of 2020.

Research limitations/implications: Using the MaCzek computer program to construct Czekanowski's diagrams, in some cases isolating similar objects in an unambiguous manner was difficult and hindered interpretation.

Originality/value: Showing that the application of Czekanowski's method to the analysis of the financial situation of public and private sector enterprises in Poland is possible and allows for the assessment of the similarity of voivodeships. The article and the application of the method is useful for entrepreneurs and investors.

Keywords: diagram of Czekanowski, net financial result, enterprices, public sector, private sector.

Category of the paper: research paper. 


\section{Introduction}

The main source of information for the assessment of the financial situation of enterprises are its financial statements. Information contained therein is very important for stakeholders when making rational decisions (eg. investment, cooperation) affecting the company. The reports are prepared in accordance with the International Financial Reporting Standards or the Accounting Act and contain integrated information on the financial results of business entities, i.e. profits achieved, revenues, costs incurred, amounts of budget liabilities or short and long-term receivables.

The basic elements of the financial statements are the balance sheet, profit and loss account, and cash flow statement. The balance sheet informs about the assets of the enterprise and the sources of its financing. The profit and loss account informs about the revenues, operating costs and financial results achieved in a given period. The cash flow statement is information about the cash flows from operating, investing and financing activities. (Wędzki, 2009) The basic tool for assessing the company's situation is the ratio analysis, which can be divided into a preliminary analysis of the financial statements (the structure of the balance sheet of the income statement and the cash flow statement, the structure of equity capital of the enterprise), the analysis of financial liquidity (from the static, income and structural point of view), and debt analysis. (level of debt and debt service capacity), business efficiency analysis (working capital cycle, cash conversion cycle, and its components), profitability analysis (sales profitability, equity and assets ratios) (Wędzki, 2009; Czekaj, Dresler, 2005).

The company's financial situation is a strong indicator of changes taking place in the company. There is a strong positive correlation between financial indicators and the investment decisions made (Kolegowicz, Krzemiński, 2019). However, the preparation of an opinion on the state of the enterprise, adequate to the current state of affairs, requires the extension of the scope of research, which cannot be limited only to the financial statements (Hamrol, 2013). The assessment of the company's financial situation should be carried out in time and space, that is, take into account internal and external conditions in the environment of the assessed enterprise. The internal conditions include the selection of appropriate tools (e.g. financial analysis) that enable the analysis of changes taking place in the enterprise and drawing correct conclusions. On the other hand, external conditions relate to the functioning of the enterprise against its environment, assessment of the strengths and weaknesses of the enterprise related to its resources, as well as opportunities and threats in its environment. As noted by M. Hamrol, the subject of the analysis should also be the relationships at the level of the industry in which the enterprise operates and the phenomena occurring in its closer and more distant environment (Hamrol, 2013). Also the results obtained by Szymańska and Jegers show a strong influence on the capital structure of both the environment and the factors generated by the sector in which the activity is conducted (Szymańska, Jegers, 2014). 
Research conducted for many years confirms that the socio-economic situation in Poland is improving every year, however, the disproportions in the level of development of voivodships remain high. The analyzes of the socio-economic development in voivodships in the voivodships in 1996-2017 carried out by A. Malina showed the existence of significant disproportions in development between the eastern and western parts of Poland, and the widening of the distance between the voivodeship with the highest and the lowest level of development. The voivodships located in western and central Poland (Mazowieckie and Wielkopolskie) are among the most developing voivodships (Malina, 2020). Similar conclusions can be drawn from the analysis carried out in the study by D. Michon (2017), where the voivodeships of the western and central (Mazowieckie) parts of the country were also identified as developing better.

The aim of the study is to determine the similarity of the financial situation of non-financial enterprises, as well as to examine whether the similarity of the taken into account financial indicators of enterprises in the analyzed voivodeships is related to their geographical location and mutual distance. An additional aim of the study is to check how the lockdown resulting from the ARS-CoV-2 pandemic influenced the financial results of Polish enterprises in the first half of 2020.

The Czekanowski diagram was used to group voivodeships in terms of the financial situation of enterprises. Such grouping will allow the voivodships to be divided into groups characterized by a high degree of mutual similarity.

The research used statistical data from the Central Statistical Office in 2010, 2019 and 2020. Due to the study of the effects of the pandemic on the financial situation of enterprises, data for the first half of each of the years mentioned were taken into account. The free MaCzek 3.3.44 program by Piotr Jaskulski and Arkadiusz Sołtysiak, available at http://www.antropologia.uw.edu.pl/MaCzek/maczek.html was used to present the results (access: 20/09/2020).

\section{The financial situation of non-financial enterprises in Poland}

Fig. 1-2 shows the financial results of Polish non-financial enterprises, taking into account the net profit and net loss for the first half of 2000-2020 for the private and public sectors. 


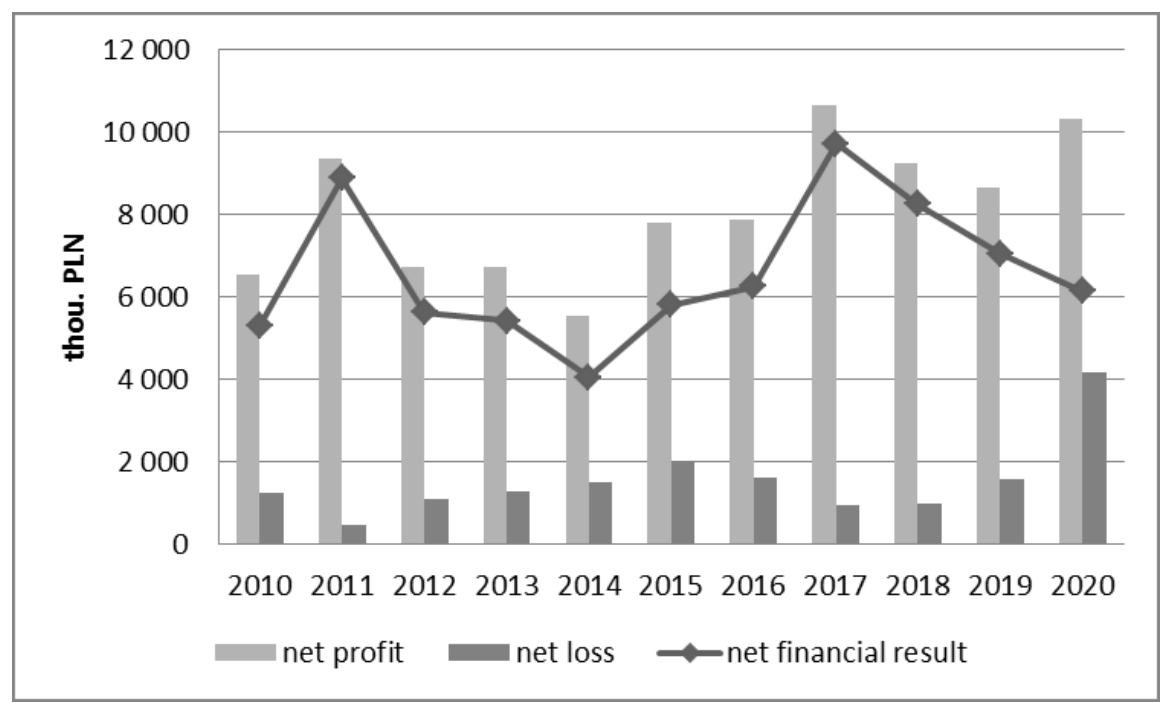

Figure 1. Net financial result, net profit and net loss of public sector non-financial enterprises in Poland for the first half of 2010-2020.

Based on the data in Figure 1, it can be seen that the highest average values of the net financial result, and also the average net profit for public sector enterprises for the first half of the year, were obtained in 2017 and 2011. Additionally, the lowest average net loss was recorded in 2011. On the other hand, the lowest average financial result was observed in the first half of 2014. Analyzing the above chart, one can also notice the impact of the pandemic on the financial result of enterprises in the first half of 2020. Despite one of the highest average net profit values in 2020, the average net loss is several times higher than in the previous years, which results in a much lower average financial result than in 2017-2019.

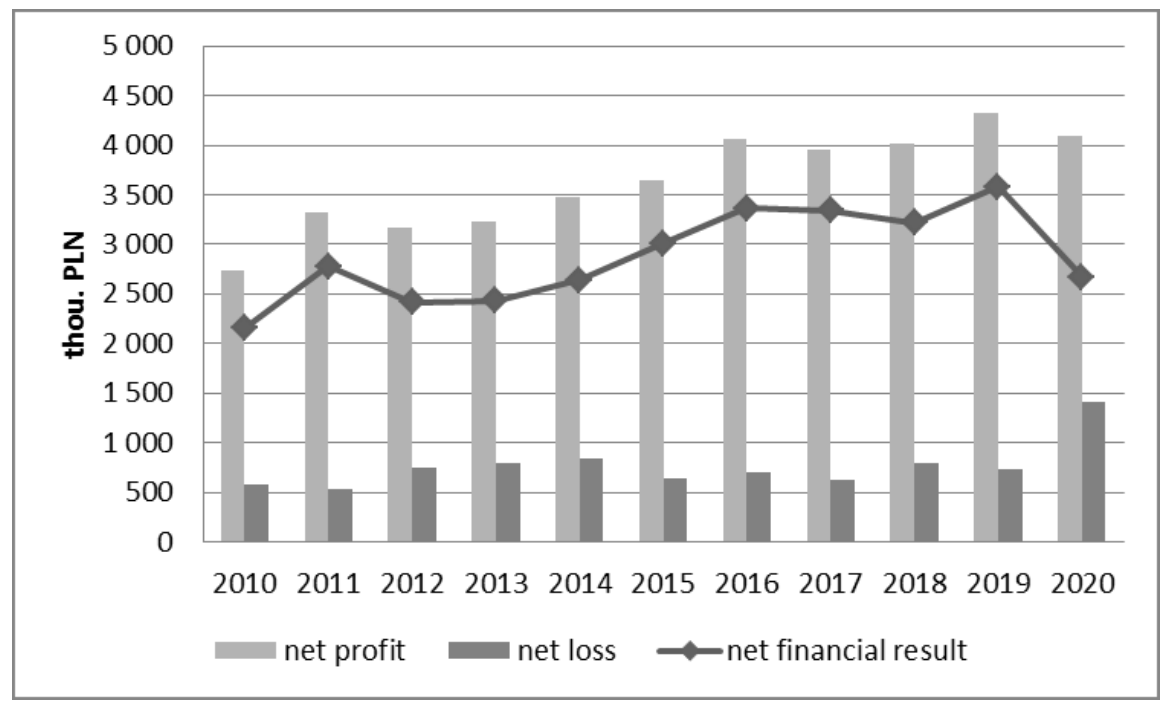

Figure 2. Net financial result, net profit and net loss of private sector non-financial enterprises in Poland for the first half of 2010-2020.

Financial data on private sector enterprises (Fig. 2) are characterized by lower values of the analyzed indicators per 1 enterprise than the indicators of public sector enterprises. The average financial result as well as the net profit reaches the highest value in the first half of 2019 . We observe the lowest average financial result in the first half of 2010. Similarly to the public 
sector enterprises, the lowest average net loss was recorded in 2011. On the other hand, in 2020 the average net loss is several times higher than in previous years, with one of the highest average net profit, which, similarly to the public sector, results in a much lower average financial result than in previous years.

Fig. 3-4 presents the average net financial result of enterprises in individual voivodeships in 2010, 2019 and 2020. The results obtained by public sector enterprises are higher than those of private sector enterprises. When analyzing the public sector (Fig. 3), it can be observed that the highest values of the average net financial result were obtained for the Mazowieckie voivodship, which despite the restrictions related to the pandemic in 2020 achieved almost $50 \%$ higher average net financial result than in 2010-2019. Among the voivodships where enterprises improved the average net financial result in the first half of 2020, the Kujawskopomorskie, Zachodniopomorskie, Warmińsko-mazurskie and Podkarpackie voivodeships can be mentioned. On the other hand, enterprises from the Śląskie and Pomorskie voivodeships recorded a net loss significantly exceeding the average net profit, which resulted in a negative net financial result. In addition, Śląskie also recorded a negative average net financial result in 2014 and 2015, and Pomorskie in 2010.
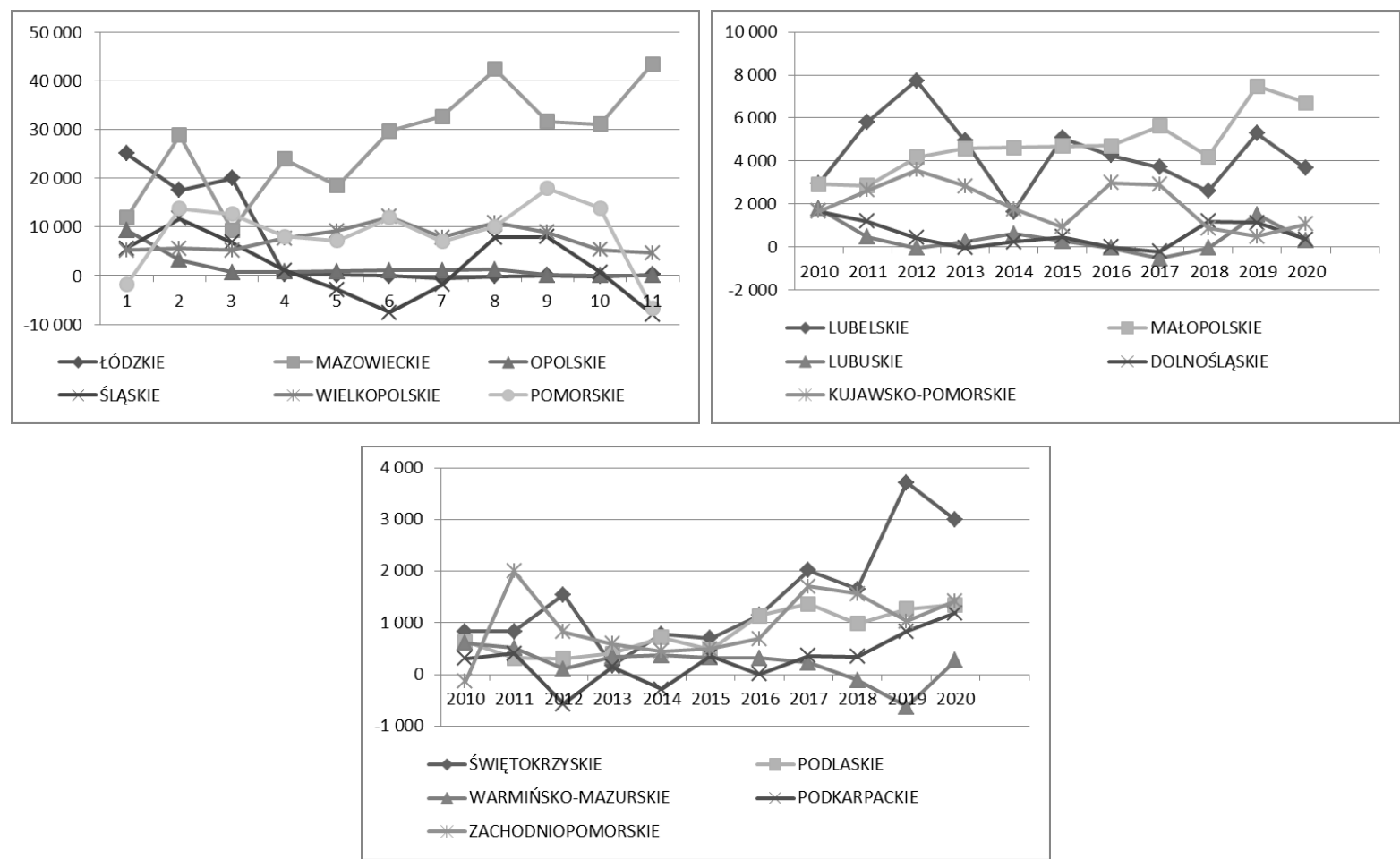

Figure 3. Net financial result of non-financial enterprises of the public sector in voivodships for the first half of the year 2010-2020. 

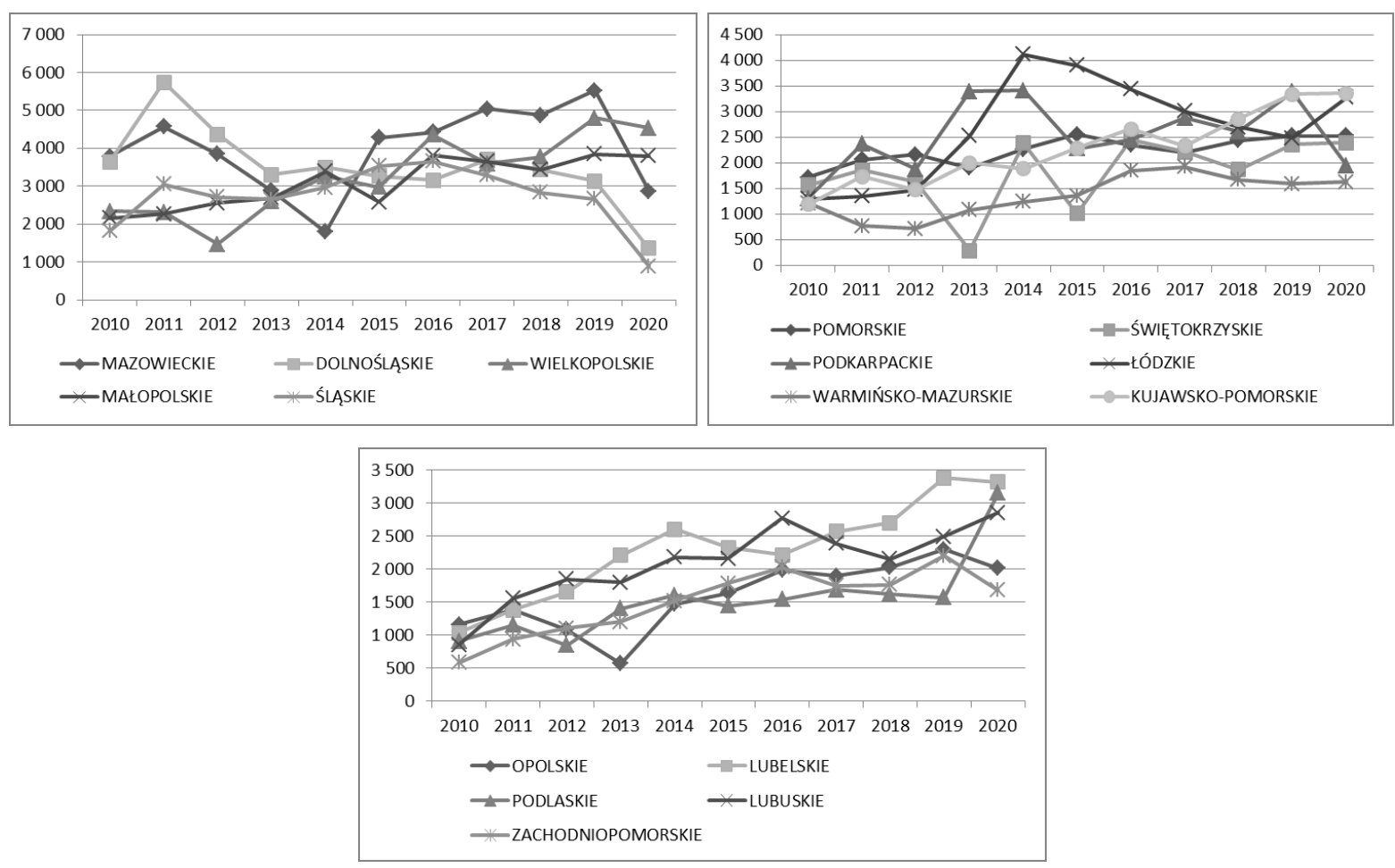

Figure 4. Net financial result of non-financial enterprises of the private sector in voivodships for the first half of the year 2010-2020.

Enterprises of the private sector (Fig. 4) are characterized by positive values of the net financial result, and for the Opolskie, Lubelskie, Lubuskie, Podlaskie and Zachodniopomorskie voivodeships a clearly upward trend can be observed. In the Podlaskie voivodeship in the first half of 2020, enterprises achieved a financial result more than twice as high as in 2019. The highest result was recorded for the Dolnośląskie voivodeship in 2011, and then for the Łódzkie Voivodeship in 2014, but in the following years we observe a downward trend in these voivodeships. As in the public sector, the highest values of the net financial result since 2015 were obtained for enterprises from Mazowieckie voivodship, which for the private sector obtained half the result. Among the voivodeships where enterprises also achieved a much lower net financial result compared to the first half of 2019, we have Podkarpackie, Dolnośląskie and Śląskie, while in the Łódzkie and Lubuskie voivodeships enterprises improved this result in the first half of 2020.

\section{The Czekanowski's diagram}

The creation of Czekanowski's diagram (Czekanowski, 1913) is one of the oldest taxonomic methods that allows to determine the relationships between objects and to visualize the relationships and similarities between them. The diagram is a visualization of the distance matrix between these objects. The objects most similar to each other are closest to the main 
diagonal of the distance matrix. The farther from the main diagonal the objects are less similar to each other (Jaskulski, Sołtysiak, 2004; Sołtysiak, Jaskulski, 1999).

The diagram is drawn according to the following stages (Heffner, Gibas, 2007):

- defining the data matrix,

- standardization or unitization of variables,

- selection of the measure of similarity,

- estimation of taxonomic distance matrices,

- determination of the minimum and maximum value in the taxonomic distance matrix,

- estimation of class intervals for taxonomic distances based on the determined empirical variability area,

- developing a disordered Czekanowski diagram,

- organizing Czekanowski's diagram,

- interpretation of obtained results.

Standardization of variables can be performed according to the formula (Dziechciarz, 2012):

$z_{i j}=\frac{x_{i j}-\bar{x}_{j}}{S_{j}}$,

where:

$z_{i j}$ - standardized variable $x_{j}$ for the $i$-th object,

$x_{i j}$ - variable $x_{j}$ for the $i$-th object,

$\bar{x}_{j}$ - arithmetic mean of the variable $x_{j}$,

$S_{j}$ - standard deviation of the variable $x_{j}$.

However, the similarity distance matrix is determined using the Euclidean metric.

\section{The empirical research}

The subject of the study were Polish voivodeships in 2010, 2019 and 2020. The study took into account over 17 thousand. enterprises from both the public sector (2010 - 1512 enterprises, 2019 - 1354 enterprises, 2020 - 1355 enterprises) and the private sector (2010 - 15707 enterprises, 2019 - 15650 enterprises, 2020 - 15764 enterprises). The data used in the analysis concerned the financial situation of all enterprises employing more than 49 people who are required to submit financial reports. The considered indicators describe the financial situation of enterprises in the analyzed voivodeships in a multilateral manner. The financial ratios were for the first half of 2010, 2019 and 2020. 
In the first stage of the research, a set of diagnostic variables was defined, eliminating the variables that are too strongly correlated with each other. Table 1 presents a set of diagnostic features taken into account in the study, taking into account the division into stimulants (S) and destimulants (D). The selection of the following measures resulted from the analysis of the factors determining the changes taking place. From among the 15 initially considered measures, due to the high degree of correlation with other variables, the following was abandoned: gross turnover profitability index, net turnover profitability index, short-term receivables, short-term investments, short-term liabilities, current assets, inventories.

\section{Table 1.}

The set of diagnostic features

\begin{tabular}{|l|l|c|}
\hline Symbol & Name & Stimulant/Destimulant \\
\hline X1 & Net profit [thou. PLN/company] & S \\
\hline X2 & Net loss [thou. PLN/enterprise] & D \\
\hline X3 & $\begin{array}{l}\text { Share of the number of enterprises with a net profit in the total number } \\
\text { of enterprises [\%] }\end{array}$ & $\mathrm{S}$ \\
\hline X4 & Cost level indicator [\%] & $\mathrm{D}$ \\
\hline X5 & Gross sales profitability indicator [\%] & $\mathrm{S}$ \\
\hline X6 & First degree financial liquidity indicator [\%] & $\mathrm{S}$ \\
\hline X7 & Second degree financial liquidity indicator [\%] & $\mathrm{S}$ \\
\hline
\end{tabular}

Then the destimulants were replaced with stimulants according to the formula (Lipieta et al., 2000):

$$
D \rightarrow S=x_{j, \max }-x_{j}
$$

In the next stage of the study, voivodeships were grouped in terms of the similarity of their financial situation of enterprises using the Czekanowski diagram. Czekanowski's diagrams for the tested objects are presented in Figs. 5-10. Individual lines and columns of the diagram correspond to the subsequent voivodeships. The larger the symbol at the intersection of the row and column, the greater the similarity of voivodships in terms of the examined features. The most similar objects are closest to the main diagonal, while the further from the main diagonal, the less similar objects in terms of the examined features.

On the basis of the diagrams created (Figs. 5-10), it can be seen that voivodships form groups of objects that are most similar to each other. However, it should be noted that in some cases the division is not clear and some voivodships can be assigned to two groups. 


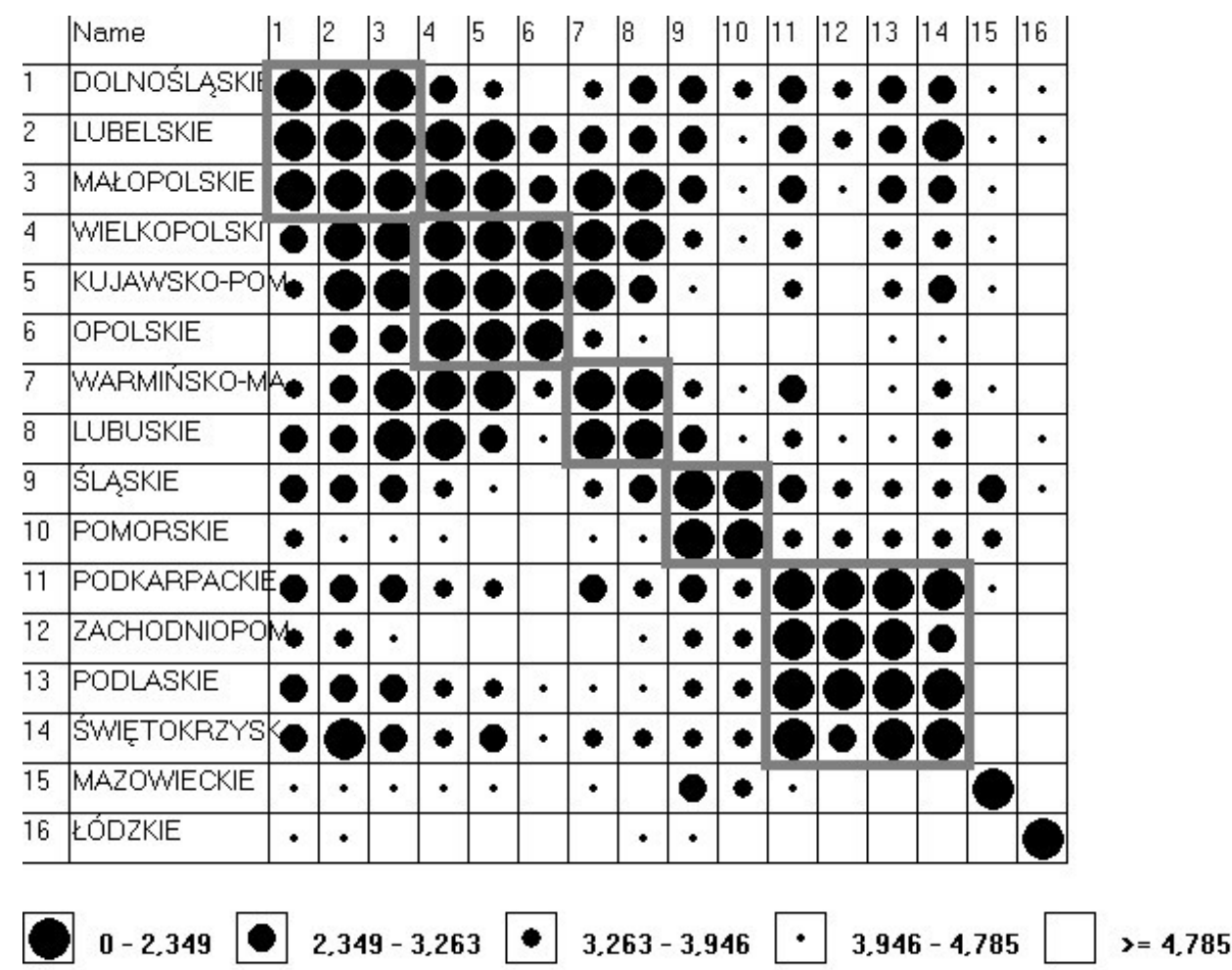

Figure 5. An orderly diagram of Czekanowski for public sector enterprises in 2010.

When analyzing the division of voivodships according to the financial situation of public sector enterprises in 2010 (Fig. 5), five groups of the most similar objects can be distinguished:

- group I: Dolnośląskie, Lubelskie, Małopolskie,

- group II: Wielkopolskie, Kujawsko-Pomorskie, Opolskie,

- group III: Warmińsko-Mazurskie, Lubuskie,

- group IV: Ślaskie, Pomorskie,

- group V: Podkarpackie, Zachodniopomorskie, Podlaskie, Świętokrzyskie.

Mazowieckie and Łódzkie voivodships do not form any groups.

The voivodships belonging to group I were characterized by the highest gross profitability ratio of public sector enterprises. The voivodeships in group II have achieved the highest 1 st and 2 nd degree financial liquidity ratios with the lowest cost ratio for almost all voivodships. Group III consists of voivodships where enterprises achieved the lowest net losses with the highest share of the number of enterprises reporting net profit in the total number of enterprises. Group IV included voivodships with enterprises with the highest values: net profit and net loss. The voivodships from group $\mathrm{V}$ were characterized by the highest values of the cost level index with the lowest gross sales profitability index and the lowest share of the number of enterprises reporting net profit. 


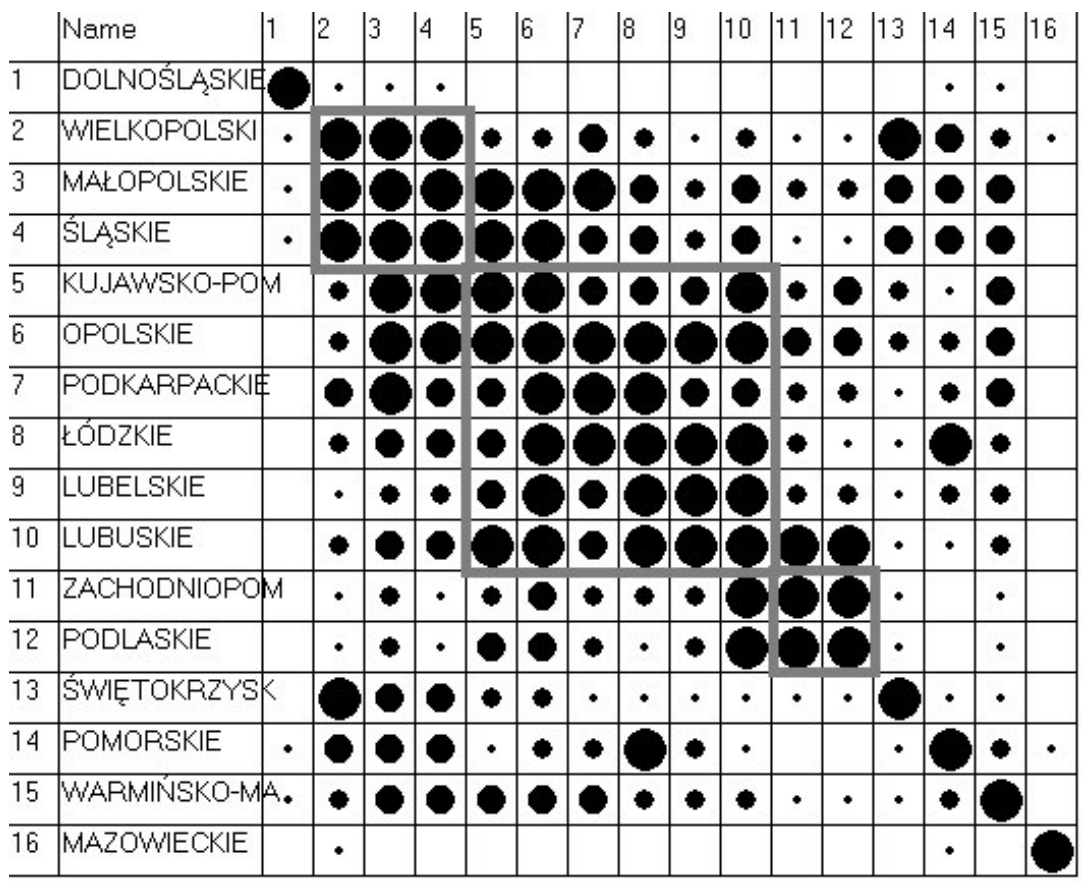

$0-2.099 \square 2.099-2,864 \bigcirc 2.864-3.545 \square 3.545-4,869 \square>4,869$

Figure 6. An orderly diagram of Czekanowski for private sector enterprises in 2010.

In the case of the private sector, in 2010 (Fig. 6), we can also distinguish three groups of the most similar voivodships in terms of the financial situation of enterprises. These are:

- group I: Wielkopolskie, Małopolskie, Śląskie,

- group II: Kujawsko-Pomorskie, Opolskie, Podkarpackie, Łódzkie, Lubelskie, Lubuskie,

- group III: Zachodniopomorskie, Podlaskie.

Dolnośląskie, Świętokrzyskie, Pomorskie, Warmińsko-Mazurskie and Mazowieckie voivodships do not form any groups.

In the private sector in 2010 , the voivodships belonging to group I were characterized by the highest level of net profit of enterprises and the highest share of the number of enterprises reporting a net profit in the total number of enterprises. Group II included voivodeships with the lowest share of the number of enterprises reporting a net profit in the total number of enterprises. On the other hand, the voivodships belonging to group III included those for which the cost level index was the highest with the lowest values: net profit, gross sales profitability index and 2nd degree financial liquidity index. 


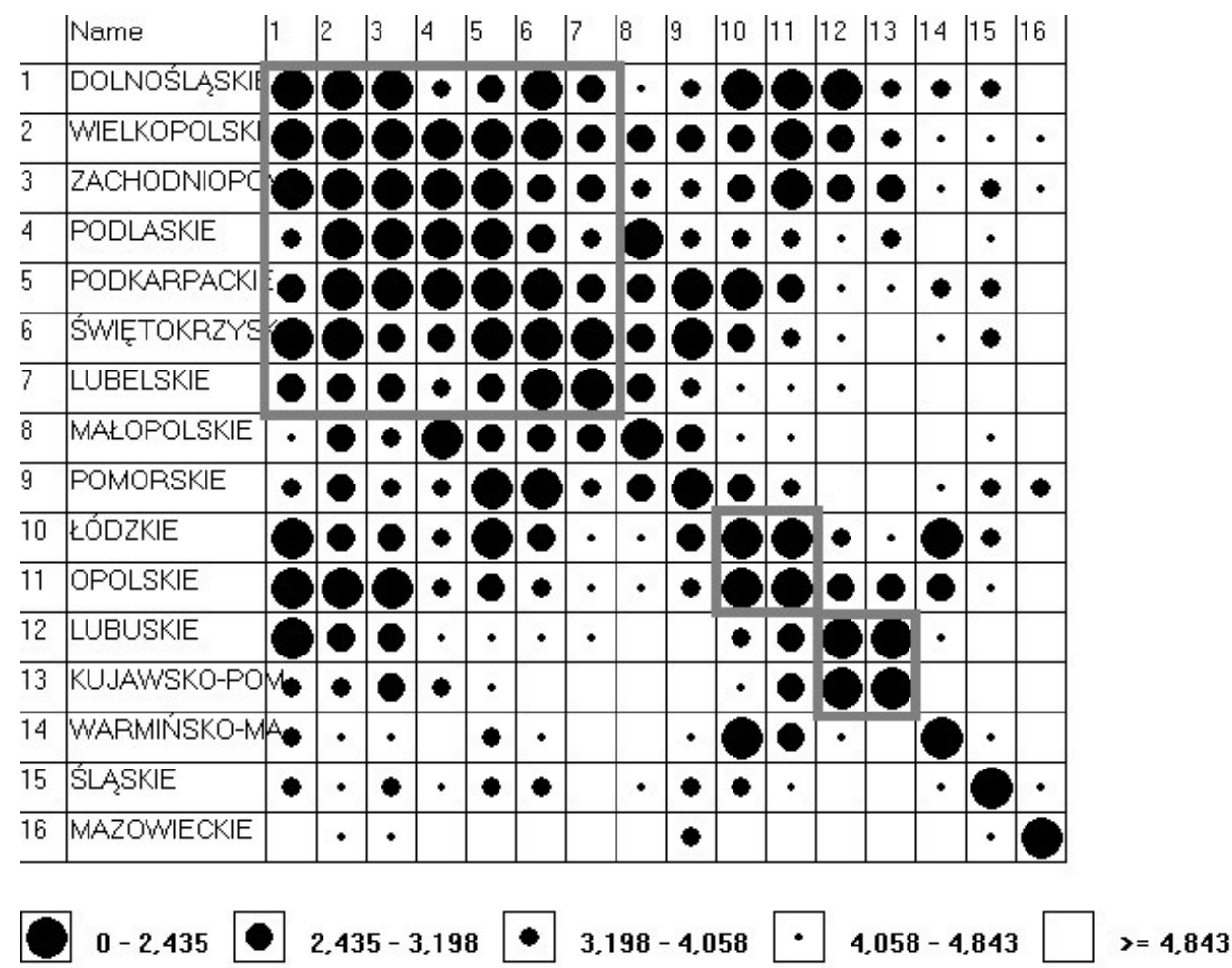

Figure 7. An orderly diagram of Czekanowski for public sector enterprises in 2019.

Based on the data contained in Figure 7, three groups of the most similar voivodeships were distinguished in terms of the financial situation of public sector enterprises in 2019. The following groups include, respectively:

- group I: Dolnośląskie, Wielkopolskie, Zachodniopomorskie, Podlaskie, Podkarpackie, Świętokrzyskie, Lubelskie,

- group II: Łódź, Opolskie,

- group III: Lubuskie, Kujawsko-Pomorskie.

The remaining Małopolskie, Pomorskie, Warmińsko-Mazurskie, Śląskie and Mazowieckie voivodships do not form any groups.

The voivodeships belonging to group I have the highest gross sales profitability ratio of public sector enterprises in 2019. with the lowest values of net loss and 2nd degree financial liquidity. The second group includes voivodeships for which the highest values achieved net profit and the cost level index, with the lowest values of the gross sales profitability index of enterprises. On the other hand, the voivodeships with the highest values of 1 st and 2 nd degree financial liquidity ratios belonged to group III. 


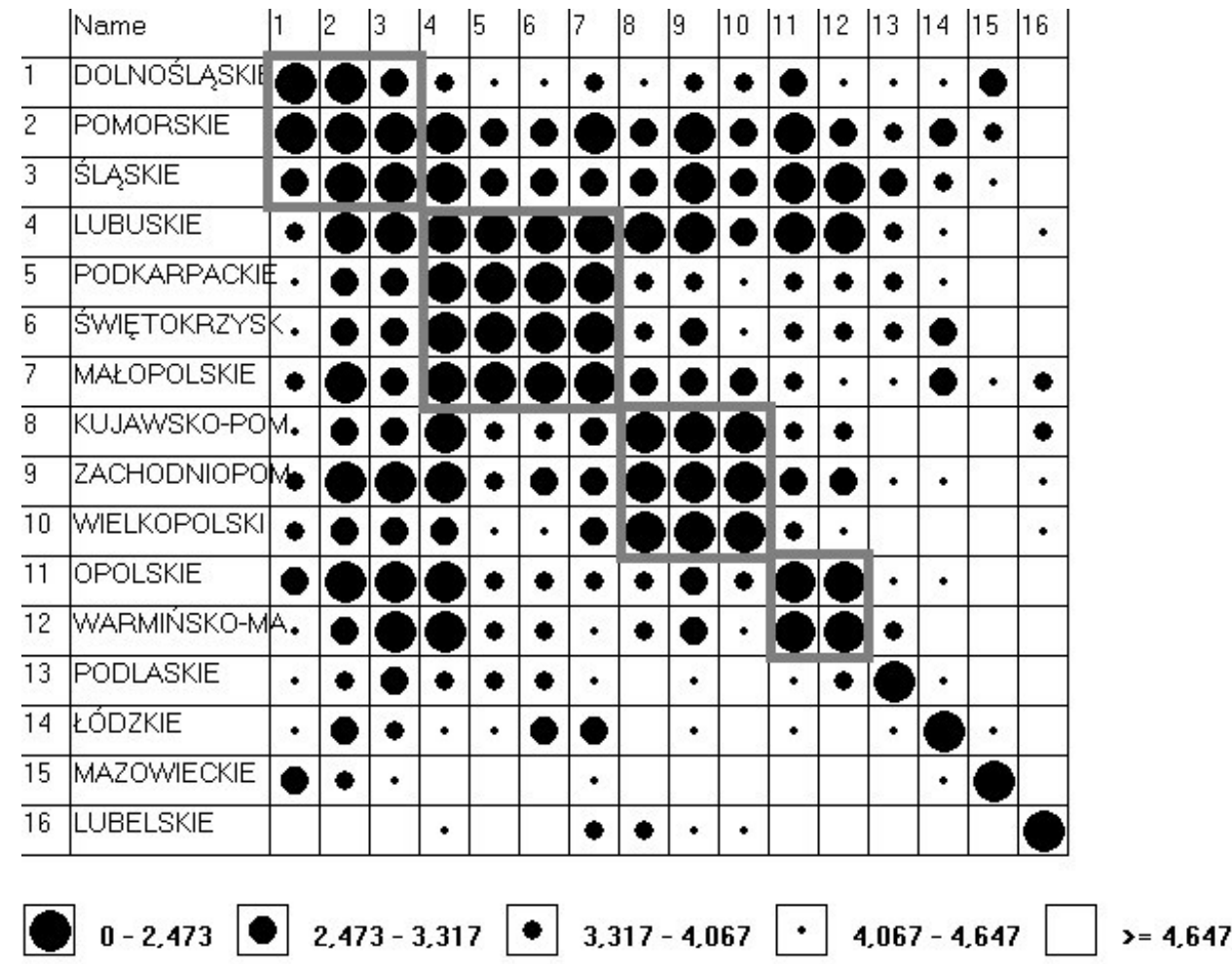

Figure 8. An orderly diagram of Czekanowski for private sector enterprises in 2019.

In the case of the private sector in 2019 (Fig. 8), four groups of the most similar voivodships can be distinguished in terms of the financial situation of enterprises. These are:

- group I: Dolnośląskie, Pomorskie, Śląskie,

- group II: Lubuskie, Podkarpackie, Świętokrzyskie, Małopolskie,

- group III: Kujawsko-pomorskie, Zachodniopomorskie, Wielkopolskie,

- group IV: Opolskie, Warmińsko-mazurskie.

As in the case of the public sector, the remaining voivodships do not form any groups.

When analyzing the private sector (Fig. 8), it can be seen that the voivodeships belonging to group I are characterized by the highest net loss of enterprises. The second group includes voivodeships for which enterprises achieved the highest values for the 1st and 2nd degree financial liquidity ratios and the lowest levels of net loss for almost all voivodships. The voivodeships belonging to group III are characterized by the highest values of gross sales profitability ratios with the lowest 2 nd degree financial liquidity ratios. On the other hand, group IV was made up of voivodships for which the share of the number of enterprises reporting net profit in the total number is the lowest. 


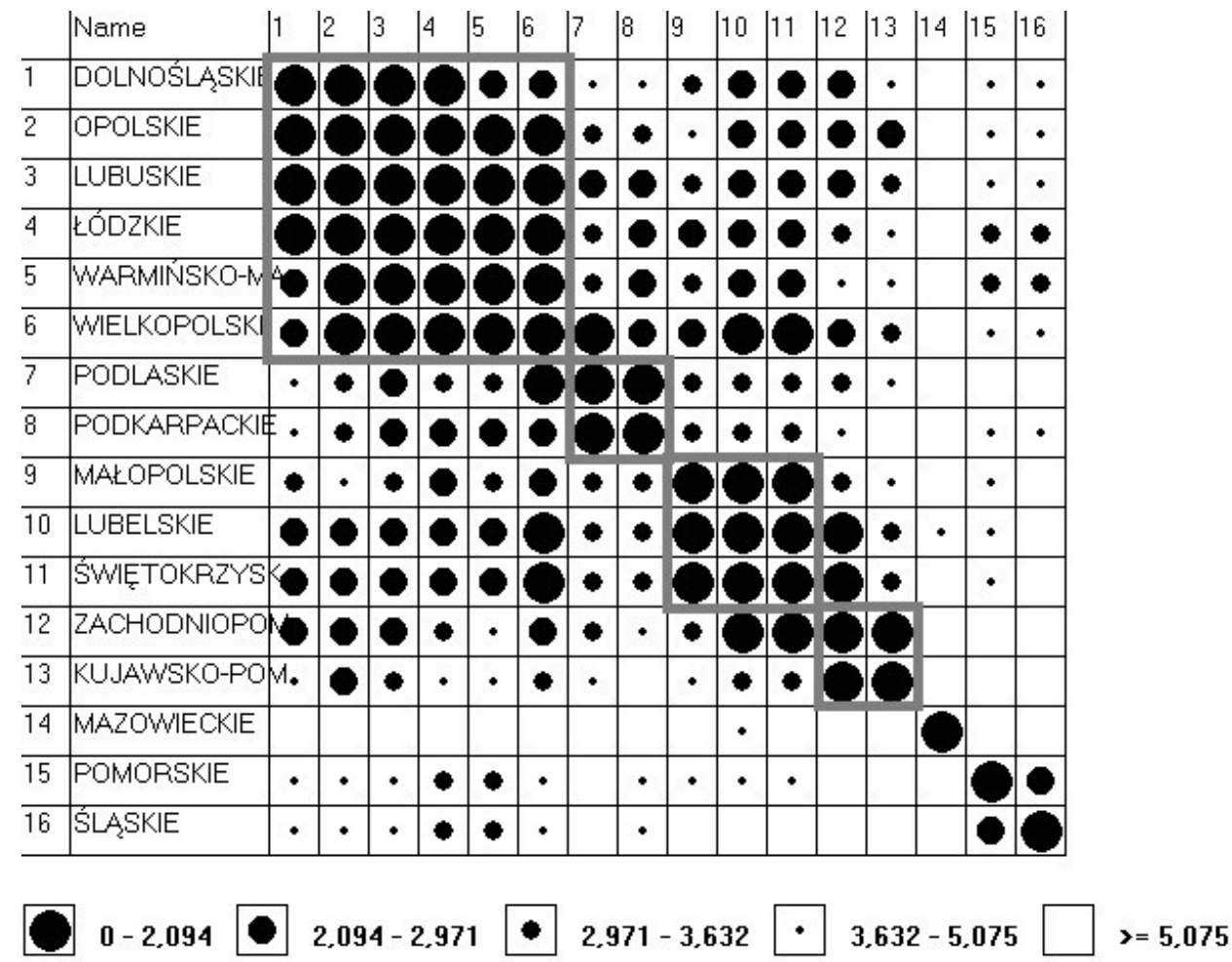

Figure 9. The orderly diagram of Czekanowski for public sector enterprises in 2020.

For public sector enterprises in 2020 (Fig. 9), four groups of the most similar voivodships can be distinguished:

- group I: Dolnośląskie, Opolskie, Lubuskie, Łódzkie, Warmińsko-Mazurskie, Wielkopolskie,

- group II: Podlaskie, Podkarpackie,

- group III: Małopolskie, Lubelskie, Świętokrzyskie,

- group IV: Zachodniopomorskie, Kujawsko-Pomorskie.

Mazowieckie, Pomorskie and Śląskie voivodships do not form any groups.

On the basis of the above diagram (Fig. 9) it can be seen that the voivodeships belonging to group I are characterized by the highest cost level index, with the lowest gross sales profitability index and the lowest net profit for almost all voivodships. The second group includes voivodships for which enterprises achieved the highest shares of the number of enterprises reporting net profit in the total number of enterprises, with the lowest values of net loss. The voivodeships belonging to group III are characterized by the highest values of gross sales profitability indexes with the lowest cost level indexes. On the other hand, group IV included voivodeships with the highest values of 1 st and 2 nd degree financial liquidity ratios. 


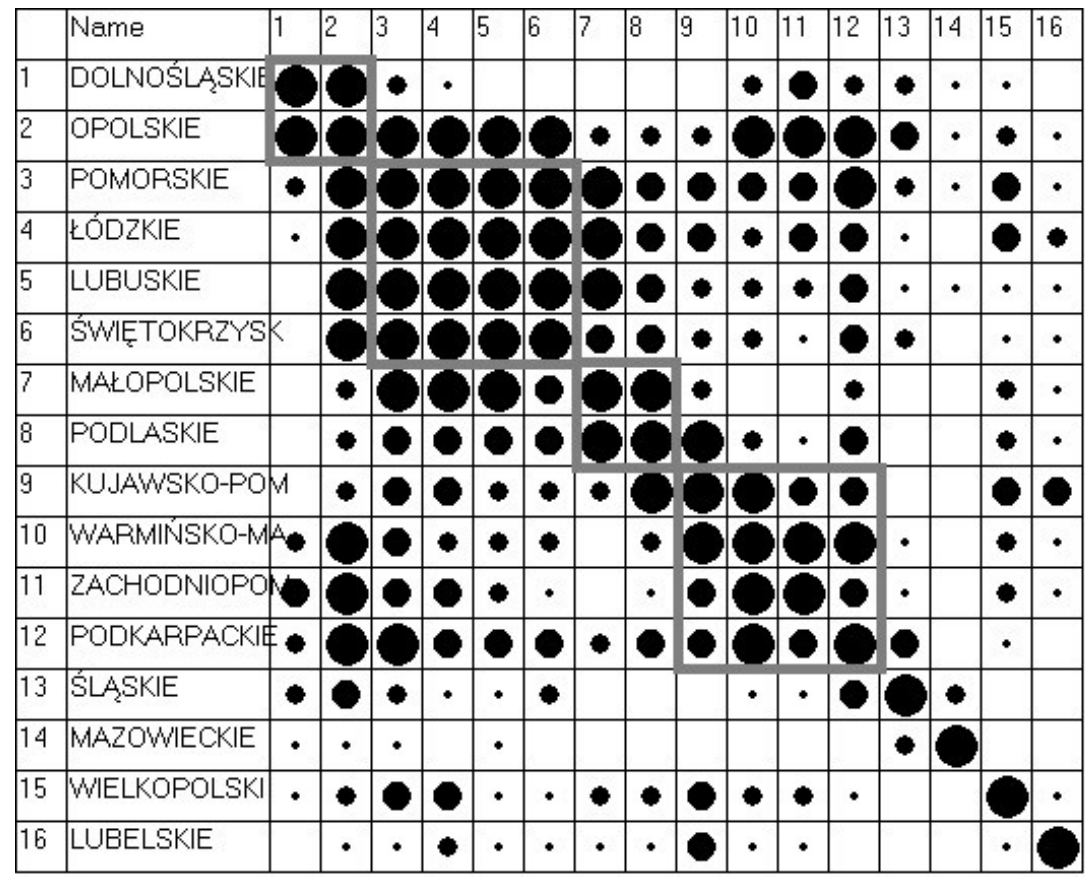

$0-2.71$

$2,71-3,193$

$3,193-3,873$

$3,873-4,674$

Figure 10. The orderly diagram of Czekanowski for private sector enterprises in 2020.

When analyzing the division of voivodships according to the financial situation of private sector enterprises in 2020 (Fig. 10), four groups of the most similar objects were distinguished:

- group I: Dolnośląskie, Opolskie,

- group II: Pomorskie, Lódzkie, Lubuskie, Świętokrzyskie,

- group III: Małopolskie, Podlaskie,

- group IV: Kujawsko-Pomorskie, Warmińsko-Mazurskie, Zachodniopomorskie, Podkarpackie.

The remaining Śląskie, Mazowieckie, Lubelskie and Wielkopolskie voivodships do not form any groups.

The voivodeships belonging to group I are characterized by the highest cost level ratio of private sector enterprises in 2020, with the lowest shares of the number of enterprises reporting net profit in the total number of enterprises. The second group includes voivodeships with enterprises with the highest value of 1 st and 2 nd degree financial liquidity ratios. Group III includes voivodeships for which enterprises achieved 2 nd degree financial liquidity ratios. However, the voivodeships with the lowest net profit belonged to group IV.

When analyzing the diagrams concerning public sector enterprises (Fig. 5, 7, 9), it can be noticed that voivodships changed their affiliation to similarity groups. The exception is Dolnośląskie, which in each of the analyzed periods was in the first group, and Mazowieckie, which never belonged to any group. Podkarpackie and Podlaskie voivodships are very similar in terms of the financial situation of enterprises in the public sector throughout the entire period. 
The remaining voivodships in each of the analyzed periods showed similarities to different voivodships.

For the private sector (Fig. 6, 8, 10) it can also be noticed that voivodships changed their affiliation to similarity groups. A great similarity between voivodships in terms of the financial situation of enterprises, which persisted throughout all the analyzed years, was noted in Lubuskie, Łódzkie and Świętokrzyskie.

Comparing diagrams 5 and 6 , it can be noticed that in 2010, both for the public sector and the private sector, almost all voivodeships were assigned to different groups due to the financial situation of enterprises. The exception is Kujawsko-Pomorskie and Opolskie, which are very similar in terms of the financial situation of enterprises both for the public sector and the private sector. In 2019, such a strong similarity between the financial situation of public and private sector enterprises was noted for the Podkarpackie and Świętokrzyskie voivodships. In 2020, however, we can observe such a similarity for the Dolnośląskie and Opolskie regions as well as for the Kujawsko-pomorskie and Zachodniopomorskie regions.

\section{Conclusion}

In the analyzed period, among the voivodships of Poland, several groups of similar voivodships can be distinguished in terms of the financial situation of enterprises. When analyzing the financial results of public sector enterprises, such groups include Podkarpackie and Podlaskie, which belong to the so-called the eastern wall and are relatively close geographically.

For the private sector, such a group consists of the Lubuskie, Łódzkie and Świętokrzyskie voivodships. The Łódzkie and Świętokrzyskie voivodeships are neighbour to each other, and the Lubuskie voivodship is quite close geographically to the Łódzkie.

In all considered cases, the Mazowieckie Voivodeship differs from the rest of the voivodships in terms of the financial situation of enterprises. It is not similar in terms of the considered features for both public and private sector enterprises.

When analyzing the financial results of non-financial enterprises in the selected period, it can be noticed that the disproportions between the western and eastern parts of the country are slowly blurring. For the public sector, the financial situation of enterprises in the Lubelskie is similar to the financial situation of enterprises from the western and central voivodeships of the country. However, the Podkarpackie and Podlaskie voivodeships still stand out from the rest, with the lowest financial results of enterprises in the public sector. On the other hand, for the private sector, the distance between the voivodships of eastern Poland and other voivodships is decreasing The exceptions are the Mazowieckie and Wielkopolskie Voivodeships, which are in the best situation in the private sector in terms of financial results. 
The financial indicators of enterprises for the first half of 2020 show the impact of the pandemic on the financial situation of enterprises in the first half of 2020. Despite one of the highest values of net profit in 2020, the value of net loss achieved by public sector enterprises is several times higher than in previous years. Private sector enterprises are in a similar situation, in 2020 the net loss is several times higher than in previous years, with one of the highest net profit values.

\section{References}

1. Czekaj, J., Dresler, Z. (2005). Zarzadzanie finansami przedsiębiorstw. Podstawy teorii. Warszawa: PWN.

2. Czekanowski, J. (1913). Zarys metod statystycznych w zastosowaniu do antropologii. Prace Naukowego Towarzystwa Warszawskiego, 5. Warszawa.

3. Dziechciarz, J. (2012). Ekonometria. Metody, przykłady, zadania. WUE, Wrocław.

4. Hamrol, M. (2013). Niedoceniane aspekty badania sprawozdania finansowego przedsiębiorstwa. Finanse, Rynki Finansowe, Ubezpieczenia, nr 59, pp. 123-132.

5. Heffner, K., Gibas, P. (2007). Analiza ekonomiczno-przestrzenna. Katowice: WUE.

6. http://www.antropologia.uw.edu.pl/MaCzek/maczek.html, 20.09.2020.

7. Jaskulski, P., Sołtysiak, A. (2004). Diagram Czekanowskiego: pomysł, historia, zastosowania. Prace Naukowe AE we Wroctawiu. Taksonomia, t. 11, nr. 1022. Klasyfikacja $i$ analiza danych - teoria i zastosowania, pp. 374-383.

8. Kolegowicz, K., Krzemiński, P. (2019). The influence of financial condition on investment decisions in enterprises in Poland. Scentific Paper of Silesian University of Technology, Organization and Management Series, No. 136, pp. 243-255.

9. Lipieta, A., Malina, A., Papież, M., Pawełek, B., Wanat, S., Zeliaś, A. (2000). Taksonomiczna analiza przestrzennego zróżnicowania poziomu życia $w$ Polsce $w$ ujęciu dynamicznym. Kraków: AE.

10. Malina, A. (2020). Analiza przestrzennego zróżnicowania poziomu rozwoju społecznogospodarczego województw Polski w latach 2005-2017. Nierówności Społeczne a Wzrost Gospodarczy, $n r$ 61(1/2020), pp. 138-155.

11. Michoń, D. (2017). Zróżnicowanie rozwoju społeczno-gospodarczego województw ze względu na realizację celów polityki spójności. Wiadomości Statystyczne, No. 12(679), pp. 80-94.

12. Sołtysiak, A., Jaskulski, P. (1999). Czekanowski's Diagram. A Method of Multidimensional Clustering. New Techniques for Old Times. CAA 98. Computer Applications and Quantitative Methods in Archaeology. Proceedings of the 26th 
Conference, Barcelona, March 1998, J.A. Barceló, I. Briz, A. Vila (eds.). BAR International Series, 757. Oxford, pp. 175-184.

13. Szymańska, A., Jegers, M. (2014). The Structure of Capital and Revenue in Social Enterprises. Ekonomia Społeczna, No. 1, pp. 51-68.

14. Wędzki, D. (2009), Analiza finansowa sprawozdania finansowego. Tom 1. Sprawozdanie finansowe. Kraków: Wolters Kluwer Polska. 